\title{
Breast-conserving treatment versus mastectomy in T1-2N0 breast cancer: which one is better for Indonesian women?
} \author{
Soehartati Gondhowiardjo ${ }^{1}$ \\ ${ }^{1}$ Department of Radiotherapy, Cipto Mangunkusumo National General Hospital, Jakarta, Indonesia \\ ${ }^{2}$ Department of Pathology, Cipto Mangunkusumo National General Hospital, Jakarta, Indonesia \\ ${ }^{3}$ Department of Internal Medicine, Cipto Mangunkusumo National General Hospital, Jakarta, Indonesia \\ ${ }^{4}$ Jakarta Breast Cancer, Jakarta, Indonesia
}

Rafiq S. Nugroho, ${ }^{1}$ Ratnawati Soediro, ${ }^{1}$ Nurjati C. Siregar, ${ }^{2}$ Zubairi Djoerban, ${ }^{3}$ Evert D.C. Poetiray, ${ }^{4}$

\begin{abstract}
Abstrak
Latar belakang: Tujuan penelitian ini adalah untuk membandingkan hasil pengobatan antara penggunaan pengobatan konservasi payudara (breast conserving therapy, BCT) dan mastektomi pada pasien kanker payudara T1-2NO.

Metode: Penelitian retrospektif ini dilakukan pada pasien kanker payudara T1-2NO yang menerima pengobatan antara Januari 2001 dan Desember 2010 di Departemen Radioterapi Rumah Sakit Cipto Mangunkusumo dan Jakarta Breast Center. Hasil akhir penelitian ini adalah kesintasan (OS), kekambuhan lokal (LR), kanker payudara kontra lateral (CBC), metastasis jauh (DM), dan disease free survival (DFS).

Hasil: Diantara 262 pasien yang memenuhi kriteria, 200 (76,3\%) pasien menjalani BCT sedangkan 62 (23,7\%) pasien menjalani mastektomi. Tidak ada perbedaan antara kelompok BCT dan mastektomi dalam hal kesintasan 5 tahun (5-yearoverall-survival) 5 -Y OS (88,2\% vs 86,7\%, $p=0,743), \operatorname{LR}(7,4 \%$ vs $2,7 \%, p=0,85), C B C(3,4 \%$ vs 5,3\%, $p=0,906), D M$ $(17,7 \%$ vs $37,7 \%, p=0,212)$, dan DFS $(78,5 \%$ vs $60,7 \%, p=0,163)$. Dalam analisis multivariat, grade 3 dikaitkan dengan OS lebih buruk (HR 2,79, 95\% CI 1,08-7,21, $p=0,03$ ) dan DFS (HR 2,32, 95\% CI 1,06-5,06). Wanita premenopause dikaitkan dengan risiko penurunan DM (HR 0,37, 95\% CI 0,17-0,80) dan DFS (HR 0,38, 95\% CI 0,19-0,78).
\end{abstract}

Kesimpulan: BCT dan mastektomi menunjukkan hasil yang sama dalam hal OS, LR, CBC, DM, dan DFS. (Med J Indones. 2012;21:220-4)

\begin{abstract}
Background: This study aimed to compare the treatment outcomes between the use of breast-conserving treatment (BCT) and mastectomy for T1-2N0 breast cancer patients.

Methods: This study retrospectively reviewed T1-2N0 breast cancer patients who received treatment between January 2001 and December 2010 at Department of Radiotherapy Cipto Mangunkusumo Hospital and Jakarta Breast Center. The endpoints of this study were overall survival (OS), local recurrence (LR), contra-lateral breast cancer (CBC), distant metastasis (DM), and disease-free survival (DFS).

Results: Among the 262 eligible patients, 200 (76.3\%) patients underwent BCT while 62 (23.7\%) patients underwent mastectomy. There were no differences between BCT and mastectomy groups in 5-Y OS (88.2\% vs $86.7 \%, \mathrm{p}=0,743)$, LR $(7.4 \%$ vs $2.7 \%, p=0.85), \mathrm{CBC}(3.4 \%$ vs $5.3 \%, p=0.906), \mathrm{DM}(17.7 \%$ vs $37.7 \%, \mathrm{p}=0.212)$, and DFS $(78.5 \%$ vs $60.7 \%$, $\mathrm{p}=0.163)$. In multivariate analysis, grade 3 was associated with worse OS (HR 2.79; $95 \%$ CI $1.08-7.21, \mathrm{p}=0.03)$ and DFS (HR 2.32; 95\% CI 1.06 - 5.06). Premenopausal women were associated with decreased risk of DM (HR 0.37; 95\% CI $0.17-0.80$ ) and DFS (HR 0.38; $95 \%$ CI $0.19-0.78$ ).
\end{abstract}

Conclusion: BCT and mastectomy showed similar outcome in terms of OS, LR, CBC, DM, and DFS. (Med J Indones. 2012;21:220-4)

Keywords: Breast-conserving treatment, mastectomy, outcomes

Breast cancer is the second most common cancer around the world with 1.38 million new cases diagnosed in 2008. While in Indonesia, this cancer is the most common cancer with 39.381 new cases diagnosed with 20.052 deaths in 2008. ${ }^{1}$ Because in the last decades more screening programs were performed, more breast cancers were detected at early stage. ${ }^{2}$

Breast-conserving treatment or mastectomy are the treatments of choice for early stage breast cancer., ${ }^{3,4}$ Both modalities provide similar treatment outcomes in terms of overall survival, loco-regional recurrence, and quality of life. ${ }^{5-7}$ Nevertheless, the use of BCT is not uniform in various countries. For example in the Netherlands, $80 \%$ of patients underwent BCT. ${ }^{8}$ In contrary, only $30 \%$ of patients underwent BCT in Hong Kong. ${ }^{9}$

In Indonesia, breast-conserving therapy or mastectomy are the standard therapies for early stage breast cancer. However, the results of treatment in Indonesia have yet to be evaluated. This study aims to compare the overall survival, recurrences, and disease-free survival between $\mathrm{BCT}$ and mastectomy for early breast cancer. 
This study is important to give recommendation for daily clinical practice.

\section{METHODS}

This is a retrospective cohort study on breast cancer patients undergoing treatment at the Department of Radiotherapy Cipto Mangunkusumo Hospital and Jakarta Breast Center between January 2001 and December 2010. The inclusion criteria were women of all ages, clinical stages T1-2N0 AJCC, histologic type of adenocarcinoma. The exclusion criteria were relapse cases with comorbidities, non-compliance to the planned treatment or progressive disease during radiotherapy. The endpoints of this study were overall survival, local recurrence, contra lateral breast cancer, distant metastasis, and disease-free survival. Data analysis was using chi square test for patient characteristics, while Kaplan-Meier with log rank test for survival analysis. Multivariate analysis of prognostic factors was using Cox regression test.

\section{RESULTS}

A number of 262 patients were included in this study, more than seventy-five percent of patients undergoing breast conserning treatment (BCT). Eleven of 200 patients who underwent BCT obtained concurrent chemotherapy. Definitive radiation therapy after breastconserving surgery is given using two-dimensional tangential technique, three-dimensional conformal techniques, or fields in the field technique covering the entire breast with doses of 50 Gy followed by a booster to tumor bed using external radiation or brachytherapy implants. Loco-regional radiation therapy was given if there was involvement of more than three positive lymph nodes, pathologically.

Table 1. Characteristics of patient with breast cancer $(n=262)$

\begin{tabular}{|c|c|c|c|c|}
\hline Variable & & $\begin{array}{l}\text { BCT } \\
\mathrm{n}(\%) \\
\end{array}$ & $\begin{array}{c}\text { Mastectomy } \\
\mathrm{n}(\%)\end{array}$ & $\mathrm{p}$ \\
\hline Age & $\begin{array}{l}<40 \text { years } \\
\geq 40 \text { years }\end{array}$ & $\begin{array}{l}40(20) \\
160(80)\end{array}$ & $\begin{array}{c}3(4.8) \\
59(95.2)\end{array}$ & 0.006 \\
\hline Menopause & $\begin{array}{l}\text { Pre menopause } \\
\text { Post menopause }\end{array}$ & $\begin{array}{c}121(61.4) \\
76(38.6)\end{array}$ & $\begin{array}{c}19(3.6) \\
43(69.4)\end{array}$ & $<0.001$ \\
\hline Site & $\begin{array}{l}\text { Right } \\
\text { Left }\end{array}$ & $\begin{array}{c}105(52.5) \\
95(47.5)\end{array}$ & $\begin{array}{l}34(54.8) \\
28(45.2)\end{array}$ & 0.747 \\
\hline Tumor Size & $\begin{array}{l}\mathrm{T} 1 \\
\mathrm{~T} 2\end{array}$ & $\begin{array}{c}56(28.4) \\
141(71.6)\end{array}$ & $\begin{array}{l}14(22.6) \\
48(77.4)\end{array}$ & 0.366 \\
\hline $\mathrm{pN}$ & $\begin{array}{l}\text { Negative } \\
\text { Positive }\end{array}$ & $\begin{array}{c}128(69.2) \\
57(30.8)\end{array}$ & $\begin{array}{l}33(60) \\
22(40)\end{array}$ & 0.203 \\
\hline Histology & Ductal invasive & $163(81.5)$ & $47(75.8)$ & 0.326 \\
\hline Margin status & $\begin{array}{l}\text { Negative } \\
\text { Close - positive }\end{array}$ & $\begin{array}{c}155(95.1) \\
8(4.9)\end{array}$ & $\begin{array}{c}28(90.3) \\
3(9.7)\end{array}$ & 0.248 \\
\hline Grade & $\begin{array}{l}1-2 \\
3\end{array}$ & $\begin{array}{l}117(82.4) \\
25(17.6)\end{array}$ & $\begin{array}{l}29(68.3) \\
13(31.7)\end{array}$ & 0.061 \\
\hline LVSI & Positive & $21(70)$ & $14(73.7)$ & 0.781 \\
\hline $\mathrm{ECE}$ & Positive & $14(36.8)$ & $11(78.6)$ & 0.008 \\
\hline ER & $\begin{array}{l}\text { Negative } \\
\text { Positive }\end{array}$ & $\begin{array}{l}94(52.8) \\
84(47.2)\end{array}$ & $\begin{array}{l}27(45.8) \\
32(54.2)\end{array}$ & 0.348 \\
\hline PR & $\begin{array}{l}\text { Negative } \\
\text { Positive }\end{array}$ & $\begin{array}{l}91(51.1) \\
87(48.9)\end{array}$ & $\begin{array}{l}30(51.7) \\
28(48.3)\end{array}$ & 0.937 \\
\hline Her-2 & $\begin{array}{l}\text { Negative } \\
\text { Positive }\end{array}$ & $\begin{array}{l}111(63.1) \\
65(36.9)\end{array}$ & $\begin{array}{l}31(55.4) \\
25(44.6)\end{array}$ & 0.302 \\
\hline Radiation therapy & & $200(100)$ & $20(32.2)$ & $<0.001$ \\
\hline Adjuvant chemotherapy & & $102(51)$ & $34(54.8)$ & 0.597 \\
\hline Hormonal therapy & & $66(33)$ & $26(41.9)$ & 0.198 \\
\hline Trastuzumab & & $14(7)$ & $7(11.5)$ & 0.289 \\
\hline
\end{tabular}

$\overline{\mathrm{pN}}=$ pathological nodes, $\mathrm{LVSI}=$ lymphovascular space invasion, $\mathrm{ECE}=$ extra capsular invasion, $\mathrm{ER}=$ estrogen receptor, $\mathrm{PR}=$ progesterone receptor 
In the mastectomy group, the most common surgical technique was modified radical mastectomy $(60 \%)$ followed by radical mastectomy $(36.8 \%)$ and simple mastectomy (3.2\%). Twenty of $62(32.3 \%)$ patients received post mastectomy radiation therapy.

The group who underwent $\mathrm{BCT}$ had more patients with age less than 40 years $(20 \%$ vs $4.8 \%, p=0.006)$ and more premenopausal patients $(61.6 \%$ vs $30.6 \%$, $\mathrm{p}<0.001)$ compared with the mastectomy group. However, the latter group had more tumors with extra capsular extension $(78.6 \%$ vs $36.8 \%, p=0.008)$ than $\mathrm{BCT}$ group. Tumor location and size, pathologic involvement of lymph nodes, histological type, surgical margin, grade, LVSI, hormonal and Her-2 status, use of adjuvant systemic therapy such as chemotherapy, hormonal, and trastuzumab did not differ between the two groups (Table 1).

In both groups there was no significant differences in the five year overall survival, local recurrence, contra lateral breast cancer, distant metastasis, and diseasefree survival (Table 2). On univariate analysis, factors affecting the overall survival is tumor size, pathology lymph node involvement, and grade. Whereas in the multivariate analysis, grade was the only an independent prognostic factor (Table 3 ).
Table 2. Comparison of treatment outcomes between BCT and mastectomy $(\%)$

\begin{tabular}{lcccc}
\hline Endpoints & Years & $\mathrm{BCT}$ & Mastectomy & $\mathrm{p}$ \\
\hline Overall survival & 5 & 88.2 & 86.7 & 0.835 \\
$\begin{array}{l}\text { Local recurrence } \\
\begin{array}{l}\text { Contra-lateral } \\
\text { breast cancer }\end{array}\end{array}$ & 5 & 7.4 & 2.7 & 0.850 \\
$\begin{array}{l}\text { Distant metastasis } \\
\begin{array}{l}\text { Disease free } \\
\text { survival }\end{array}\end{array}$ & 5 & 17.7 & 37.7 & 0.212 \\
\hline value obtained from Kaplan Meier with log-rank test & 5 & 78.5 & 60.7 & 0.163 \\
\hline
\end{tabular}

Fifty-two of 259 (16.2\%) patients had recurrence, 45 patients (17.4\%) had distant recurrence (metastasis), ten patients $(3.9 \%)$ experienced recurrence in the contra lateral breast. Local and regional recurrence occurred in twelve and two patients each (4.6\% and $0.8 \%)$.

On univariate analysis, prognostic factors for the occurrence of distant metastases were menopausal status, tumor size, grade. Whereas in the multivariate analysis, menopausal status was an independent prognostic factor for metastasis. The prognostic factors for disease-free survival were grade and menopausal status in both univariate and multivariate analysis (Table 4).

Table 3. Prognostic factors analysis for treatment outcomes

\begin{tabular}{|c|c|c|c|c|c|c|}
\hline & \multirow{2}{*}{ Variable } & \multirow{2}{*}{ OS } & \multicolumn{3}{|c|}{ Recurrences } & \multirow{2}{*}{ DFS } \\
\hline & & & LR & $\mathrm{CBC}$ & DM & \\
\hline Treatment & $\begin{array}{l}\text { BCT } \\
\text { Mastectomy }\end{array}$ & 0.835 & 0.850 & 0.906 & 0.212 & 0.163 \\
\hline Age & $\begin{array}{l}<40 \text { years } \\
\geq 40 \text { years }\end{array}$ & 0.161 & 0.566 & 0.527 & 0316 & 0.691 \\
\hline Menopause & $\begin{array}{l}\text { Pre menopause } \\
\text { Post menopause }\end{array}$ & 0.180 & 0.583 & 0.748 & 0.009 & 0.006 \\
\hline Tumor size & $\begin{array}{l}\mathrm{T} 2 \\
\mathrm{~T} 1\end{array}$ & 0.038 & 0.316 & 0.183 & 0.033 & 0.430 \\
\hline $\mathrm{pN}$ & $\begin{array}{l}\text { Positive } \\
\text { Negative }\end{array}$ & 0.031 & 0.797 & 0.498 & 0.061 & 0.241 \\
\hline Margin & $\begin{array}{l}\text { Negative } \\
\text { Close-Positive }\end{array}$ & 0.799 & 0.532 & 0.672 & 0.196 & 0.176 \\
\hline Grade & $\begin{array}{l}3 \\
1-2\end{array}$ & 0.003 & 0.294 & 0.259 & 0.038 & 0.030 \\
\hline LVSI & $\begin{array}{l}\text { Positive } \\
\text { Negative }\end{array}$ & 0.338 & 0.515 & 0.114 & 0.838 & 0.705 \\
\hline ER & $\begin{array}{l}\text { Negative } \\
\text { Positive }\end{array}$ & 0.134 & 0.826 & 0.737 & 0.922 & 0.613 \\
\hline PR & $\begin{array}{l}\text { Negative } \\
\text { Positive }\end{array}$ & 0.300 & 0.796 & 0.253 & 0.181 & 0.203 \\
\hline Her-2 & $\begin{array}{l}\text { Negative } \\
\text { Positive }\end{array}$ & 0.250 & 0.558 & 0.773 & 0.295 & 0.360 \\
\hline
\end{tabular}

$\overline{\mathrm{pN}}=$ pathological nodes, $\mathrm{LVSI}=$ lymphovascular space invasion, $\mathrm{ER}=$ estrogen receptor, $\mathrm{PR}=$ progesterone receptor 
Table 4. Multivariate analysis using cox regression model

\begin{tabular}{lccc}
\hline & HR & $95 \%$ CI & $\mathrm{p}$ \\
\hline Overall survival & & & \\
T2 vs T1 & 2.338 & $0.51-10.65$ & 0.272 \\
pN positive vs negative & 1.634 & $0.66-4.08$ & 0.293 \\
$\quad$ Grade 3 vs 1-2 & 2.796 & $1.08-7.21$ & 0.033 \\
Distant metastasis & & & \\
Pre vs post menopause & 0.366 & $0.17-0.80$ & 0.012 \\
T2 vs T1 & 1.524 & $0.57-4.05$ & 0.398 \\
Grade 3 vs 1-2 & 2.211 & $0.95-5.14$ & 0.065 \\
Disease free survival & & & \\
Pre vs post menopause & 0.379 & $0.19-0.78$ & 0.008 \\
Grade 3 vs 1-2 & 2.323 & $1.07-5.06$ & 0.034 \\
\hline
\end{tabular}

\section{DISCUSSION}

During the last thirty years, treatment for early-stage breast cancer has shifted from mastectomy to BCT. Between 1980 and 2004, the use of mastectomy at the Mayo Clinic dropped from $91 \%$ to $36 \%{ }^{10}$ In four of the nine Dutch Comprehensive Cancer Centers, the majority of early-stage breast cancer patients received BCT (87-99\%). ${ }^{8}$ However, in Hong Kong as well as in Sabah Malaysia, the use of BCT was only $30 \%$ and $22.5 \%$, respectively. ${ }^{9,11}$

$\mathrm{BCT}$ is more widely used in patients with younger age ( $\leq 40$ years). In the Dutch Comprehensive Cancer Center, patients with age older than 75 years are associated with decreased use of radiotherapy compared to patients younger than 55 years (OR 0.4; $95 \%$ CI from 0.4 to 0.5$).{ }^{10}$ The same result has been obtained from research in the U.S.A. ${ }^{12}$

Definitive radiation therapy decreased local recurrence after lumpectomy from $39.2 \%$ to $14.3 \%$ in a study conducted by the NSABP B-06. ${ }^{13}$ Meta-analysis conducted by the EBCTCG showed that radiotherapy after breast-conserving surgery decreased local recurrence within 5 years and mortality in 15 years by $19 \%$ and $5.4 \% .^{14}$

Several studies have shown that breast conserving therapy and mastectomy provided equivalent survival. The study from North Carolina showed that mastectomy and BCT gives the same 5 year-survival-rate $(94.8 \%$ and $96.7 \%$, HR $1.3395 \%$ CI 0.86 to 2.05 ). ${ }^{15}$ Rapiti et al reported that the 10 years survival in patients who underwent $\mathrm{BCT}$ and mastectomy did not differ significantly (HR $0.69 ; 95 \%$ CI 0.46 to 1.03$).{ }^{16} \mathrm{~A}$ study in Korea showed that 10 year overall survival in patients receiving BCT and mastectomy were $91.96 \%$ and $91.01 \%(p=0.127) .{ }^{17}$ EORTC 10.801 study reported that the 10 year-survival-rate is similar between mastectomy and BCT $(66 \%$ vs $61 \%, \mathrm{p}=0.1) .{ }^{18}$ The 20 years follow-up showed that there was no difference in term of overall survival between mastectomy and BCT for early stage breast cancer $(41.2 \%$ and $41.7 \%, \mathrm{p}=$ 1.0). ${ }^{19}$ This study also proved similar result in terms of overall survival. We found that the prognostic factors for overall survival were tumor size, pathologic lymph node involvement, and grade.

Several studies reported that local recurrence occurred more of ten in patients who received BCT compared to mastectomy. EORTC reported that 5 and 10 years loco regional recurrences were higher in BCT group than mastectomy $(11.8 \%$ and $19.7 \%$ vs $9.8 \%$ and $12.2 \%$, p $=0.0097) \cdot{ }^{18}$ Veronessi et al reported that the incidence of local recurrence in 20 years on breast conservation therapy group was higher than mastectomy $(8.8 \pm$ $3.2 \%$ vs $2.3 \pm 0.8, \mathrm{p}<0.001) .{ }^{19} \mathrm{~A}$ randomized study in Europe showed that local recurrence in the BCT group was higher than mastectomy. ${ }^{20}$ Meta-analysis reported that there were no differences in terms of $3,5,15$, and 20 years loco-regional recurrences between $\mathrm{BCT}$ and mastectomy group. But for 10 year, loco-regional recurrence was higher in $\mathrm{BCT}$ than mastectomy (OR $1.55 ; 95 \%$ CI 1.05 to 2.30$){ }^{6}$ In this study, 5 year local recurrence in patients who underwent $\mathrm{BCT}$ was higher than mastectomy but not statistically significant. This is similar to a study in Korea, where 23 patients (3.8\%) in the BCT and 22 patients $(2.1 \%)$ in the mastectomy group had local recurrence $(\mathrm{p}=0.081) .{ }^{17}$

In general, radiotherapy is not associated with an increased risk of contra-lateral breast cancer. The risk of contra-lateral breast cancer after radiotherapy is associated with the increase of follow-up. At followup for five years, radiotherapy was not associated with risk. However, after five years, radiotherapy is associated with slightly increased risk of contra-lateral breast cancer (1.14, 95\% CI 1.03 to 1.26$).{ }^{21}$ Incidence of contra-lateral breast cancer for 5, 10, 15, 20 years in patients receiving radiotherapy is $2.9 \%, 6.5 \%$, $10.2 \%$, and $13.4 \%$, whereas in patients not receiving radiotherapy it is $3 \%, 6 \%, 8.9 \%$, and $11.8 \%{ }^{22}$

In this study, there were no significant differences in patients undergoing BCT compared with mastectomy. This is probably due to lack of follow-up time.

Distant metastases in patients who underwent BCT or mastectomy did not differ significantly. Voogd et al reported that the incidence of distant metastasis for 5 and 10 years in patients with early stage breast cancer after BCT were $24 \%$ and $34 \%$ while mastectomy were $24 \%$ and $32 \%(\mathrm{p}=0.36) \cdot{ }^{20}$ Research in Korea showed that 
5 years distant metastasis after BCT and mastectomy were $9.7 \%$ and $12.4 \%$, respectively. In these patients, 59.2 to $69.4 \%$ received adjuvant chemotherapy and 50.1 to $53.6 \%$ received hormonal therapy. ${ }^{17}$ EORTC study showed that the 10 years distant metastasis in patients receiving $\mathrm{BCT}$ and mastectomy were $26.8 \%$ and $26.7 \%$ respectively $(p=0.24) .{ }^{18}$ Veronessi reported in patients with T1N0 breast cancer during follow-up of 20 years that the rates of distant metastases in patients with breast conserving therapy and mastectomy were $23.3 \%$ and $24.3 \%{ }^{19}$ This current study provided similar results between two group. Factors that influence metastasis are among others menopausal status, tumor size and grade.

In conclusion, the treatment options for early stage breast cancer (T1-2N0) can be either BCT (breast-conserving surgery followed by definitive radiation therapy) or mastectomy depending on patient preference because both treatment modalities gave similar outcomes. In patients who expect the preservation of the breast, breast-conserving therapy can be considered. Whereas in patients who want to avoid radiotherapy, a mastectomy may be considered. Prospective studies with large numbers of subjects are needed to find out the role of prognostic factors, treatment efficacy for recurrence both local and contra lateral breast cancer, as well as the effect of systemic therapy to reduce distant metastases.

\section{REFERENCES}

1. Ferlay J, Shin HR, Bray F, Forman D, Mathers C, Parkin DM. GLOBOCAN 2008 v1.2, Cancer incidence and mortality worldwide: IARC Cancer Base No. 10 [Internet]. Lyon, France: International Agency for Research on Cancer; 2010 [cited 2011 Nov 03]. Available from: http://globocan.iarc.fr.

2. American Cancer Society. Cancer facts \& figures 2012. Atlanta: American Cancer Society; 2012. p. 1-28.

3. National Cancer Institute. $\mathrm{PDQ}{ }^{\circledR}$ breast cancer treatment. Bethesda, MD: National Cancer Institute; 2011 [cited 2012 May 03]. Available from: http://www.cancer.gov/ cancertopics/pdq/treatment/breast/healthprofessional.

4. Ruppel MB, Cole DJ. Symptomatic breast cancer. In: Poston GJ, Beauchamp RD, Ruer TJM, editors. Textbook of surgical oncology. United Kingdom: Informa UK Ltd; 2007. p. 115.

5. Poortmans P. Evidence based radiation oncology: breast cancer. Radiother Oncol. 2007;84:84-101.

6. Yang SH, Yang KH, Li YP, Zhang YC, He XD, Song AL, et al. Breast conservation therapy for stage I or stage II breast cancer: a meta-analysis of randomized controlled trials. Ann Oncol. 2008;19:1039-44.

7. Munshi A, Dutta D, Kakkar S, Budrukkar A, Jalali R, Sarin $\mathrm{R}$, et al. Comparison of early quality of life in patients treated with radiotherapy following mastectomy or breast conservation therapy: a prospective study. Radiother Oncol. 2010;97:288-93.

8. Struikmans H, Aarts MJ, Jobsen JJ, Koning CC, Merkus JW, Lybeert ML, et al. An increased utilization rate and better compliance to guidelines for primary radiotherapy for breast cancer from 1997 till 2008: a population-based study in the Netherlands. Radiother Oncol. 2011;100:320-5.

9. Yau TK, Soong IS, Sze H, Choi CW, Yeung MW, Ng WT, et al. Trends and patterns of breast conservation treatment in Hong Kong: 1994-2007. Int J Radiat Oncol Biol Phys. 2009;74:98-103.

10. Keshtgar M, Davidson T, Pigott K, Falzon M, Jones A. Current status and advances in management of early breast cancer. Int J Surg. 2010;8:199-202.

11. Leong BDK, Chuah JA, Kumar VM, Rohamini S, Siti ZS, Yip CH. Trends of breast cancer treatment in Sabah, Malaysia: a problem with lack of awareness. Singapore Med J. 2009; 50(8):772-6.

12. Anderson WF, Reiner AS, Matsuno RK, Pfeiffer RM. Shifting breast cancer trends in the United States. J Clin Oncol. 2007;25:3923-9.

13. Fisher B, Anderson S, Bryant J, Margolese RG, Deutsch M, Fisher ER, et al. Twenty-year follow-up of a randomized trial comparing total mastectomy, lumpectomy, and lumpectomy plus irradiation for the treatment of invasive breast cancer. N Engl J Med. 2002;347:1233-41.

14. Early Breast Cancer Trialists' Collaborative Group (EBCTCG). Effects of radiotherapy and of differences in the extent of surgery for early breast cancer on local recurrence and 15-year survival: an overview of the randomised trials. Lancet. 2005;366:2087-106.

15. Simsek F. Five year survival analysis of patients with clinical stages I and IIA breast cancer who received initial treatment at North Carolina Hospital. Center for Health Informatics and Statistics. 2000;123:1-9.

16. Rapiti E, Fioretta G, Vlastos G, Kurtz J, Schafer P, Sappino $\mathrm{AP}$, et al. Breast-conserving surgery has equivalent effect as mastectomy on stage I breast cancer prognosis only when followed by radiotherapy. Radiother Oncol. 2003;69:277-84

17. Noh JM, Park W, Huh SJ, Choi DH, Yang JH, Nam SJ, et al. A comparison of clinical outcomes for breast-conserving treatment and mastectomy for early breast cancer. J Korean Soc Ther Radiol Oncol. 2008;26(1):10-6.

18. Van Dongen JA, Voogd AC, Fentiman IS, Legrand C, Sylvester RJ, Tong D, et al. Long-term results of a randomized trial comparing breast-conserving therapy with mastectomy: European Organization for Research and Treatment of Cancer 10801 trial. J Natl Cancer Inst. 2000;92:1143-50.

19. Veronesi U, Cascinelli N, Mariani L, Greco M, Saccozzi $\mathrm{R}$, Luini A, et al. Twenty-year follow up of a randomized study comparing breast-conserving surgery with radical mastectomy for early breast cancer. $\mathrm{N}$ Engl J Med. 2002;347(16):1227-32.

20. Voogd AC, Nielson M, Peterse JL, Blichert-Toft M, Bartelink H, Overgaard M, et al. Differences in risk factor for local and distant recurrence after breast-conserving therapy or mastectomy for stage I and II breast cancer: pooled results of two large European randomized trials. J Clin Oncol. 2001;19:1688-97.

21. Gao X, Fisher SG, Emami B. Risk of second primary cancer in the contralateral breast in women treated for early-stage breast cancer: a population-based study. Int J Radiat Oncol Biol Phys. 2003;56(4):1038-45.

22. N, Triaspolitica. "Kanker Payudara: Informasi, Penyebab, Gejala, Stadium Dan Pengobatan." Mau Nanya Dong Dok. N.p, 28 June 2017. Web. 30 June 2017. $<$ https://nanyadongdok.blogspot.com/2017/06/kankerpayudara-informasi-penyebab.html $>$. 